\title{
Evolution to Emergence of Green Buildings: A Review
}

\author{
Jam Shahzaib Khan ${ }^{1, *}$, Rozana Zakaria ${ }^{1, *}$, Siti Mazzuana Shamsudin ${ }^{2}$, \\ Nur Izie Adiana Abidin ${ }^{1}$, Shaza Rina Sahamir ${ }^{2}$, Darul Nafis Abbas ${ }^{1}$ and Eeydzah Aminudin ${ }^{1}$ \\ 1 School of Civil Engineering, Faculty of Engineering, Universiti Teknologi Malaysia, 81310 Skudai, Johor, \\ Malaysia; izieadiana@gmail.com (N.I.A.A.); darulnafis@gmail.com (D.N.A.); eeydzah@utm.my (E.A.) \\ 2 Faculty of Architecture, Planning and Survey, Universiti Teknologi MARA, 40450 Shah Alam, Selangor, \\ Malaysia; mazzuana5962@gmail.com (S.M.S.); rinashaza@gmail.com (S.R.S.) \\ * Correspondence: skjam2@graduate.utm.my (J.S.K.); rozana@utm.my (R.Z.); Tel.: +60-13-779-1810 (R.Z.)
}

Received: 31 August 2018; Accepted: 30 November 2018; Published: 10 January 2019

\begin{abstract}
Green Buildings" are essential in being responsive to the challenges of climate change and global warming while inhibiting natural resources degradation. This demand requires specific attention to increase the adoption of green-certified buildings within the construction industry. Innovative tools and techniques are needed to meet global challenges and strategies set for Sustainable Development Goals of 2030 agenda. This paper provides an intensive review of the evolution of green buildings from a sustainable development perspective which investigates the current global adoption of green buildings. Systematic Literature Review (SLR) and Selective Critical Literature Review Analysis (SCLRA) methodologies were adopted focusing on the content analysis to develop more in-depth knowledge. The scope of this study enlightens the sustainable development goals and initiatives. This paper highlighted that there is still inadequate adoption of green buildings and their rating tools on a significant basis in developing countries. This research adds a method towards the better understanding of green buildings and current scenarios that shall be considered for future research.
\end{abstract}

Keywords: sustainability; sustainable development; green buildings; green building rating tools

\section{Introduction on Green Buildings}

The world is moving faster towards a global agenda which is underpinned by the Sustainable Development Goals (SDGs) initiatives. These goals imply a sustainable development direction which resulted in the concept of green buildings and emerged as a new trend in the innovative technological field of built environment. Many developed and developing countries have set goals and strategies to prioritize planning and actions that would capture the green building ventures (Kibert 2004). The concept of green buildings has evolved in an astonishing way to achieve sustainable development (Hamid et al. 2014; Zuo and Zhao 2014; Bradley Guy and Kibert 1998; Kibert 2004).

Green buildings are designed to reduce their impacts on climate change and conserve natural resources through different phases of design, construction, operation, maintenance, and demolition (Zuo and Zhao 2014). With the innovative sustainable practices in building construction, governments, organizations, and all other building stakeholders are engaged in positive learning, benefiting the idea of green building from its conceptuality to the reality of construction and operation. Green buildings promise to reduce energy consumption, conserve the environment, utilize building materials from economic resources and preserve social equality among their occupants. In recent years, developers, designers, investors and building owners have become interested in building green buildings (Hamid et al. 2014). Green buildings provide lucrative benefits to all stakeholders in terms of efficient service 
to quality of life and better livability for future generations. However, a lack of research and studies related to the costs and benefits of green buildings undermines the ability to determine the value of this investment (Hu et al. 2014).

Moreover, Green buildings have great potential in playing their role to diversify built environment projects in various corners of social, economic and environmental development (Hu et al. 2014). The adventure of green buildings is more fascinating due to its contribution towards better social and economic growth and environmental preservation. The concept of the green building is more attractive due to its fringe benefits and incentives that collectively offer a better future for the construction industry and indirectly establishes a better globe to live in (Chew et al. 2017). Additionally, green buildings are not only designed to save energy and resources but also use recycled materials and minimize the emissions of toxic substances throughout their life cycles (Awadh 2017).

\section{Evolution from "Sustainable Development to Green Buildings"}

The report published by the World Commission on Environment and Development (WCED) in 1987 named "Our Common Future" presented a classical definition of sustainable development as "development which meets the needs of the present without compromising the ability of future generations to meet their own needs" (WCED 1987). Achieving sustainable development is not an easy task, it needs tools, techniques, drivers, action plans, indicators and long term adoption of these assets across every project (Plessis 1999). During world forums of sustainable development spanning many decades, researchers and scientists have been striving to set goals and develop strategies in a multi-directional approach to carry such a development which does not affect our future generations in any of the aspects of the Triple Bottom Line (TBL), "social, economic, and environmental".

Sustainable development has become one of the main challenges the entire world faces (Awadh 2017). In forums and research studies, it has been mentioned that the depletion of natural resources, environment, economy, and society has led the globe towards the emerging path of sustainable development (Grafakos et al. 2016; United Nations Publcation 2007). The approach of keeping the balance of usage and return in terms of resources is a key element of sustainability and sustainable development (Aras and Crowther 2009). Shiel et al. (2016) mentioned that sustainable development is needed in order to mitigate the long-term impact for present or future generations. This is due to the current advancement of technology, climate change, growth of population and globalization in the economy. All of these factors contribute to inequality and dynamic changes of political and environment conditions, a lack of resources, and impact on energy consumption patterns and its production. In addition, Phillis and Andriantiatsaholiniaina (2001) noted that sustainable development is an effort to ensure that all societies in this world enjoy sufficiently high standards of living in a of new era of building and infrastructure development without having a disruption in natural resources.

The need to emphasize the urgency of sustainable development provokes the adoption of green buildings; however both the terms "sustainable development and green buildings" are interlinked (World Green Building Council 2017). This paves the same path through applications interconnected to each other Sustainable development follows the path towards the successful achievement of sustainability and this cannot be obtained by pursuing one without the other (Leiper et al. 2003). Meanwhile, green buildings can address the key requirements of sustainability such as the efficient use of energy and water, the reduction of consumption of natural resources, and improving the environment and health (Dwaikat and Ali 2018). Over many decades, the world has been drastically focusing on green buildings to achieve sustainable development through integrated sustainable development goals and vice versa. Grafakos et al. (2016) mentioned that this movement of sustainable development and green buildings enhances the capacity of the global environment. This will manage the emerging needs of a population that is growing drastically and fulfilling infrastructure needs for years to come in a sustainable way.

Figure 1 shows the viable, bearable and equitable sustainable living growth by three laps that represent 2015, 2030 and 2050 in billion meter squares. The dramatic growth of building floor area 
needed a systematic plan and strategic management of available resource (tools and techniques) for green building adoption. Thus, green buildings meet nine different Sustainable Development Goals.

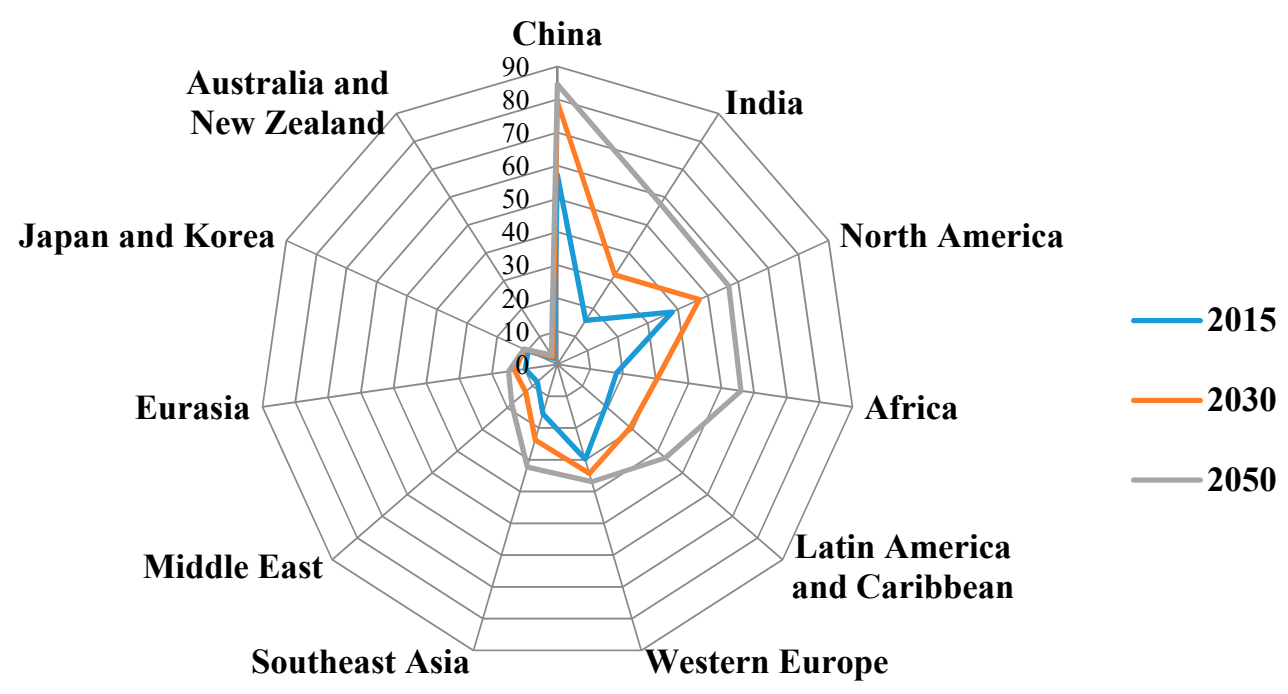

Figure 1. Building Floor Area growth by Region in Billion $\mathrm{m}^{2}$. Source: (Towards Low-GHG and Resilient Buildings 2016).

Keeping in mind the drastic growth of building floor area, researchers have developed different types of techniques to optimize sustainable development in various aspects of life. Hence, the construction industry is considered as one of the major contributors to the "Triple Bottom Line" of sustainable development. However, the construction industry has developed the new trend of optimizing built environment infrastructure with green technology and green buildings. Conversely, Doan et al. (2017) claimed that there are many differences in concepts of sustainable development and it does comply but is not limited to just the triple bottom line. There are certainly many things that can be integrated with the framework of sustainable development to indulge green building practices (Beatty 2011). However, Doan et al. (2017) also showed that shades of sustainable development and green building frameworks encompass environmental significance through various parameters compared to traditional buildings. In addition, they further claimed that sustainable buildings focus on four pillars such as social, economic, institutional and leading. Hence, there are emerging updates on green buildings and it is anticipated that in the near future, more pillars will be merged within the framework of green buildings.

\section{Research Methodology}

The systematic review enhances the capability of research in terms of finding the most relevant and rational literature available. The procedure begins with identifying and adopting keywords then browsing the internet with reliable journals, their references, and citation indexes. The searching process was formulated in a range of focused categories starting from sustainable development, green buildings, green building rating tools, green building reviews, etc. However, the search was carried on online available sources such as published papers, books, and reports. Additionally, content analysis was also carried for the literature that has been downloaded to examine the literature.

The aim of conducting this search was to identify and analyze green building adoption within the construction industry from published articles according to time frame (year) and the set of key words identified for this research. Objectives were set to compare various conventional reviews through systematic review that is an eminent technique of reproducing scientific, transparent and in-depth processes. This was carried out with a view to understand plans of green development in developed and developing countries. The process is mostly similar to the systematic review analysis method that was developed by (Cook et al. 1997) and has been endorsed in various research articles (Keyvanfar et al. 
2014; Shafaghat et al. 2016). Systematic review has been considered as a fundamental scientific activity (Keyvanfar et al. 2014). The fundamental scientific activity provides an overwhelming opportunity for thoroughgoing literature review in search of published and unpublished research with the trail of audit from their review and procedural conclusions. Figure 2 demonstrates the flow chart of Systematic Literature Review (SLR) with the objectives being to find relative research available in various databases and analyze the evolution and emergence of green buildings. It started with online keywords searches for "Green Buildings, Green Building Rating Tools, Life Cycle Costing, Automation in GBRT, and Sustainable Development to integration of green building rating tool with other tools". These key words outlined findings mentioned in Integrated Matrix Selective Critical Literature Review Analysis (SCLRA).

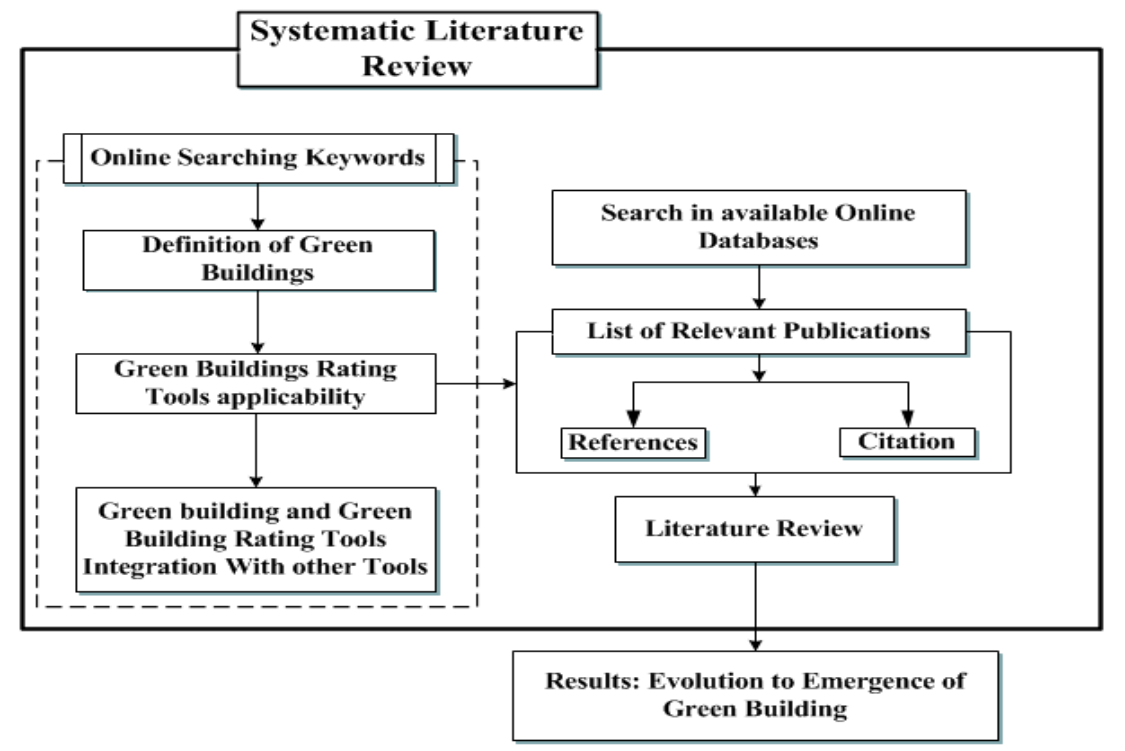

Figure 2. Flow Chart of Systematic Literature Review.

The research endeavored rigorous Systematic Literature Review (SLR) and Selective Critical Literature Review Analysis (SCLRA) methodologies. The focus was to identify ample studies that are similar in connection to the set of keywords. The methodology adopted the four-way technique of identification, screening, eligibility and included. Therefore, 102 research articles related to the study were downloaded in which 30 were excluded on the basis of scope; and the remaining 80 were kept as eligible. Keeping the research focus on priority, this research included 62 published research articles for Systematic Literature Review. All the published articles were also scrutinized through Selective Critical Literature Review Analysis which resulted in 30 main published articles being mentioned in an integrated matrix of selective critical literature review analysis (SCLRA).

\section{Current Adoption of Green Buildings Globally and Specifically in Malaysia}

The World Green Building Council (WGBC) mentioned in annual report of 2015-2016 that buildings account for $30 \%$ of $\mathrm{CO}_{2}$ emissions with a 7.4 billion world population (WGBC 2016; The World Bank 2017). Nonetheless, by the year 2030 there will be 8.5 billion people on the globe with $90 \%$ living in developing countries (WGBC 2016). This will bring huge impacts on the globe and on available natural resources. Similarly, the United Kingdom Green Building Council (UKGBC) stated that United Nations Environment Program (UNEP) in 2012 also mentioned some key statistics with facts and figures about the global built environment and the value of green buildings (UK-Green Building Council 2014). The given facts and figures were that the global built environment is responsible for $30-40 \%$ of global energy consumption that accounts for the $30 \%$ of greenhouse gas emissions. Furthermore, annually 3 billion tons of raw material consumed and $20 \%$ of water used globally. However, green buildings can deliver a $30-50 \%$ reduction in energy usage, a $35 \%$ decrease in CO 
emissions, with a tremendous decrease of $70 \%$ in waste generation; and finally they would provide a $40 \%$ reduction in the usage of water (UNEP 2012; UK-Green Building Council 2014). Aktas and Ozorhon (2015) described green buildings as being meant to be designed and operated to abbreviate the overall impact of the built environment on its environs and green building rating tools adds in incentives for more green building development.

Recently in July 2017, the United States Green Building Council (USGBC) updated statistics and mentioned that there are more than 90,500 total commercial and LEED+ND (LEED-Neighborhood Development) certified projects within 167 countries and territories (USGBC 2017). The LEED+ND program was designed to develop a sophisticated connected neighborhood providing all communities with better living standards (USGBC-LEED+ND 2014). Moreover, World Green Building Trends evaluated in their report of 2016 presented by Dodge data and analytics "the first market intelligence and collaboration platform for construction industry" that many investors and developers are expecting to have $60 \%$ of their projects certified as green and by 2018 this will be doubled from $18 \%$ to $37 \%$ globally (WGBT 2016). On the other hand China has also paved the path for 3-star green buildings and certified about 200 government buildings as 3-star green buildings (Zhou 2014). The Canada Green Building Council released a report called Canada Green Building Trends 2014; the report claimed that over $30 \%$ of the projects developed in Canada are green and by 2017 the figure will be more than double (McGraw Hill Construction 2014). They further added that the client demand is one of the top triggers where $82 \%$ of building occupants, owners and developers reported a decrease in energy consumption; and $68 \%$ showed a decrease in water consumption compared to conventional buildings (McGraw Hill Construction 2014; Doan et al. 2017). The return on investment plays a crucial role in such types of new green buildings. The investors and companies show a lack of enthusiasm in moving further towards green buildings due to uncertainty on their return on investment. The tropical zones like Malaysia also initiated their path towards green buildings and developed the Green Building Index (GBI) as a green building assessment and rating tool by the Malaysian Green Building Confederation (MGBC 2017) to meet the challenges of the Sustainable Development Goals of 2030.

In 2016, at the International Urban Sustainability and Green Building Conference organized by the Malaysian Green Building Confederation (MGBC), it was announced that the Green Building Index (GBI) has achieved a sustainability milestone with a 150-million square foot mark of gross floor area of certified GBI buildings (Greenbuildingindex Sdn Bhd 2016). They further announced that during the two years before 2016, a 100-million square foot milestone was achieved and this is represents a dramatic $50 \%$ increase. This marks another achievement of largest gross floor area certified by a single green certified organization in Malaysia (MGBC 2016). Furthermore, Table 1 showed that a total of 815 projects was registered from January 2017 to December 2017 and out of these 815 registered projects, a total of 435 were certified by the Green Building Index, Malaysia. This assessment shows that $53.3 \%$ projects achieved certification and also indicates that the green building certification trend has room to improve by obtaining the interest of investors and builders to develop green buildings (MGBC 2016). Khan et al. (2018) mentioned that in green building development, a higher initial cost are a major factor, therefore by providing various cost effective, efficient, easy and quick integrated methods of green building rating tools integrated with life cycle costing, elements can achieve more targets. 
Table 1. Recent Overview of Green Certified Building in Malaysia.

\begin{tabular}{|c|c|c|c|c|c|c|c|c|c|c|c|c|c|c|c|c|}
\hline \multirow[b]{2}{*}{ Stage } & \multicolumn{12}{|c|}{$\begin{array}{l}\text { Recent Overview of the Green Certified Buildings by GBI-Malaysia from Jan-Dec } 2017 \\
\text { (DA-Design Assessment, CVA-Completion \& Verification Assessment, RVA-Renewal Verification Assessment) }\end{array}$} & \multirow{2}{*}{\multicolumn{2}{|c|}{ ID Interior }} & \multirow{2}{*}{\multicolumn{2}{|c|}{$\mathrm{T}$ (Township) }} \\
\hline & \multicolumn{2}{|c|}{$\begin{array}{l}\text { Total as of } \\
\text { Year } 2017\end{array}$} & \multicolumn{2}{|c|}{$\begin{array}{l}\text { Non-Residential } \\
\text { New } \\
\text { Construction } \\
\text { (NRNC) }\end{array}$} & \multicolumn{2}{|c|}{$\begin{array}{l}\text { Residential New } \\
\text { Construction } \\
\text { (RNC) }\end{array}$} & \multicolumn{2}{|c|}{$\begin{array}{l}\text { Industrial New } \\
\text { Construction } \\
\text { (INC) }\end{array}$} & \multicolumn{2}{|c|}{$\begin{array}{l}\text { Non-Residential } \\
\text { Existing } \\
\text { Building } \\
\text { (NREB) }\end{array}$} & \multicolumn{2}{|c|}{$\begin{array}{c}\text { Industrial } \\
\text { Existing } \\
\text { Building (IEB) }\end{array}$} & & & & \\
\hline & Jan-17 & Dec-17 & Jan-17 & Dec-17 & Jan-17 & Dec-17 & Jan-17 & Dec-17 & Jan-17 & Dec-17 & Jan-17 & Dec-17 & Jan-17 & Dec-17 & Jan-17 & Dec-17 \\
\hline Applied & 774 & 877 & 407 & 473 & 298 & 316 & 24 & 34 & 22 & 24 & 4 & 5 & NA & 1 & 19 & 24 \\
\hline Registered & 723 & 815 & 377 & 437 & 283 & 299 & 21 & 30 & 20 & 21 & 3 & 4 & NA & 1 & 19 & 23 \\
\hline & 380 & 435 & 188 & 218 & 159 & 178 & 9 & 11 & 13 & 13 & 3 & 3 & & 1 & 8 & 11 \\
\hline Total Certified & $100 \%$ & $100 \%$ & $49 \%$ & $50 \%$ & $42 \%$ & $41 \%$ & $3 \%$ & $2 \%$ & $3 \%$ & $3 \%$ & $1 \%$ & $1 \%$ & NA & $1 \%$ & $2 \%$ & $2 \%$ \\
\hline Provisional Certification DA & 306 & 340 & 152 & 173 & 133 & 142 & 5 & 7 & 7 & 6 & 1 & 1 & NA & 0 & 8 & 11 \\
\hline Final Certification CVA & 68 & 86 & 32 & 40 & 26 & 36 & 2 & 2 & 6 & 5 & 2 & 2 & NA & 1 & 0 & 0 \\
\hline Renewal Certification RVA & 6 & 8 & 4 & 4 & 0 & 0 & 2 & 2 & 0 & 2 & 0 & 0 & NA & 0 & 0 & 0 \\
\hline Renewal Certification 2nd RVA & 0 & 1 & 0 & 1 & 0 & 0 & 0 & 0 & 0 & 0 & 0 & 0 & NA & 0 & 0 & 0 \\
\hline
\end{tabular}


The descent in the global financial market is affecting the property and real estate market globally (WGBT 2016) and investors might assume that the green building boom is near the end or on hold (Deng and Wu 2014). This impact might also trigger investor interest towards green buildings, which is why green building attractiveness needs to be updated with new innovative tools and technologies (Li et al. 2017). In many countries around the world, client demand is increasing for green buildings and investors need to understand time factors to set their strategies accordingly (Olubunmi et al. 2016).

The Malaysian government has set goals to meet the challenges of 2030 with the initial targets set for 2016-2020; this was briefed in a multi-stakeholder partnership workshop session (Economic Planning Unit Malaysia 2016). Various thrusts and game changers have been identified and some of them directly or indirectly linked to the construction industry of Malaysia as shown in Figure 3. Therefore, various tools and techniques with integrated approach are needed to uplift the construction industry of Malaysia. These strategic plans will befittingly benefit in satisfying sustainable cities and communities with green certified infrastructure marks. The facts show the dearth of green building development, as mentioned in Table 1. This also identifies that the construction industry has to be equipped with innovation tools to meet such challenges and bring investors and developers towards green certified building by providing them with a better, efficient and effective automated system of green building assessment with life cycle cost analysis.

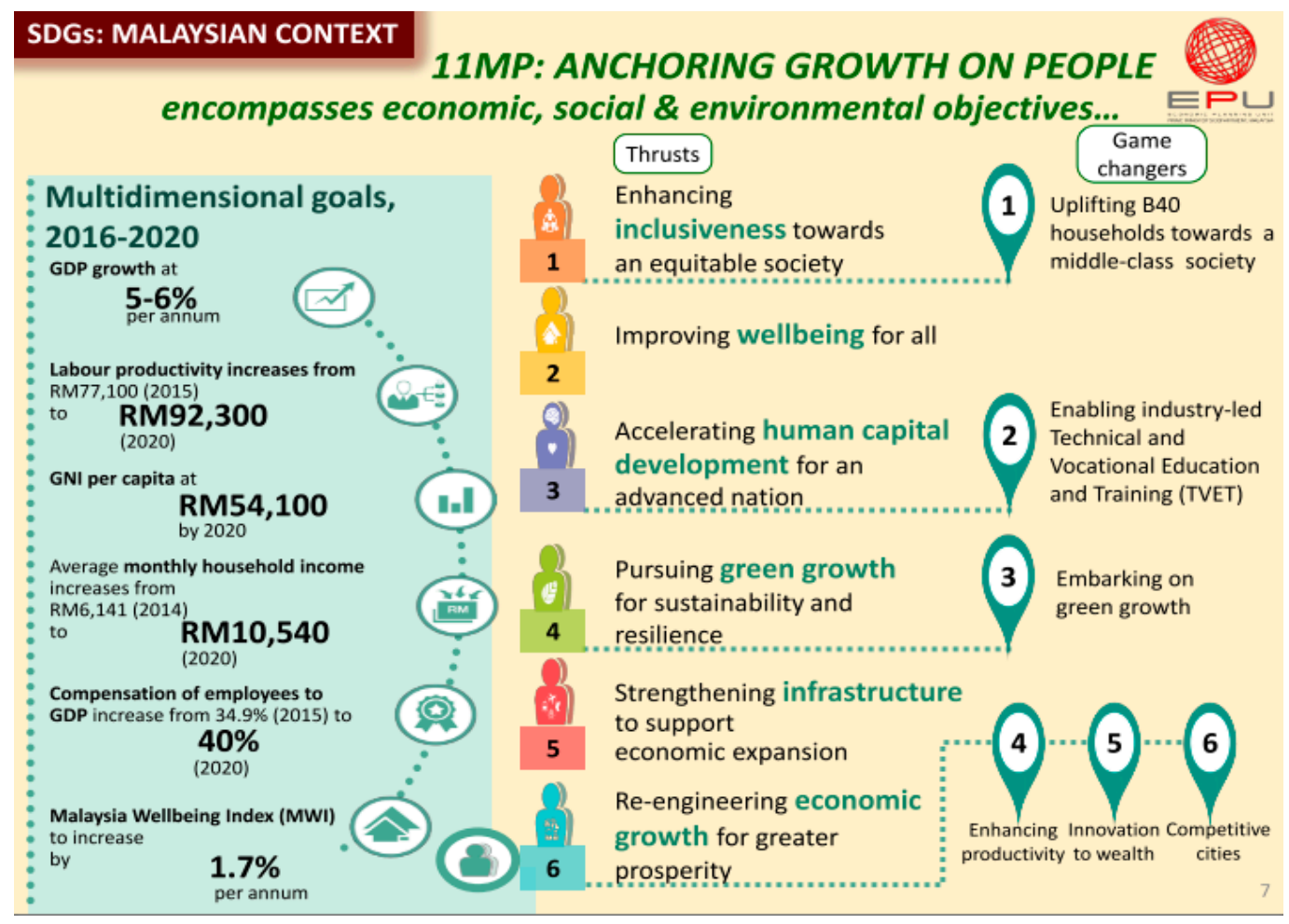

Figure 3. Malaysian Plan for Sustainable Development Goals. Source: Sustainable Development in Malaysia: “2030 AGENDA IN THE NATIONAL CONTEXT AND SDG ROADMAP” EPU, Malaysia.

\section{Content Analysis on Green Buildings and Green Building Rating Tools}

Many developed and developing countries have established their own tools to assess the green building and apply those tools to achieve sustainable development through green building technology (Say 2008). This journey of green buildings and green building rating tools was started in 1990 by BREEAM, United Kingdom. By the year 2010, there were 382 types of registered building software in the world (Poveda and Young 2015). The World Green Building Council is playing a vital role in revitalizing the green building rating assessment and certification system. In 2015, World Green Building Council has introduced "Quality Assurance Guide for Green Building Rating Tools" for the 
new rising developers of rating tools in order to ensure that development and implementation is transparent and of good quality standards (WGBC 2017). By 2016, their members certified 1.04 billion square meters of green building space around the world; this counts as an area 10 times the size of Paris (WGBC 2016). The results identified that most of the green building research published from 2011-2015 with the $50 \%$ of the portion portrayed drastic increments, while whereby in previous periods, from 1999-2005, only 8\% of research has been conducted. Moreover, from 2006-2010 only $16 \%$ of the existing green building research was conducted and published. Figure 4 also shows 2011-2015 has been dominant span in which most of studies have been performed on the set of identified key words.

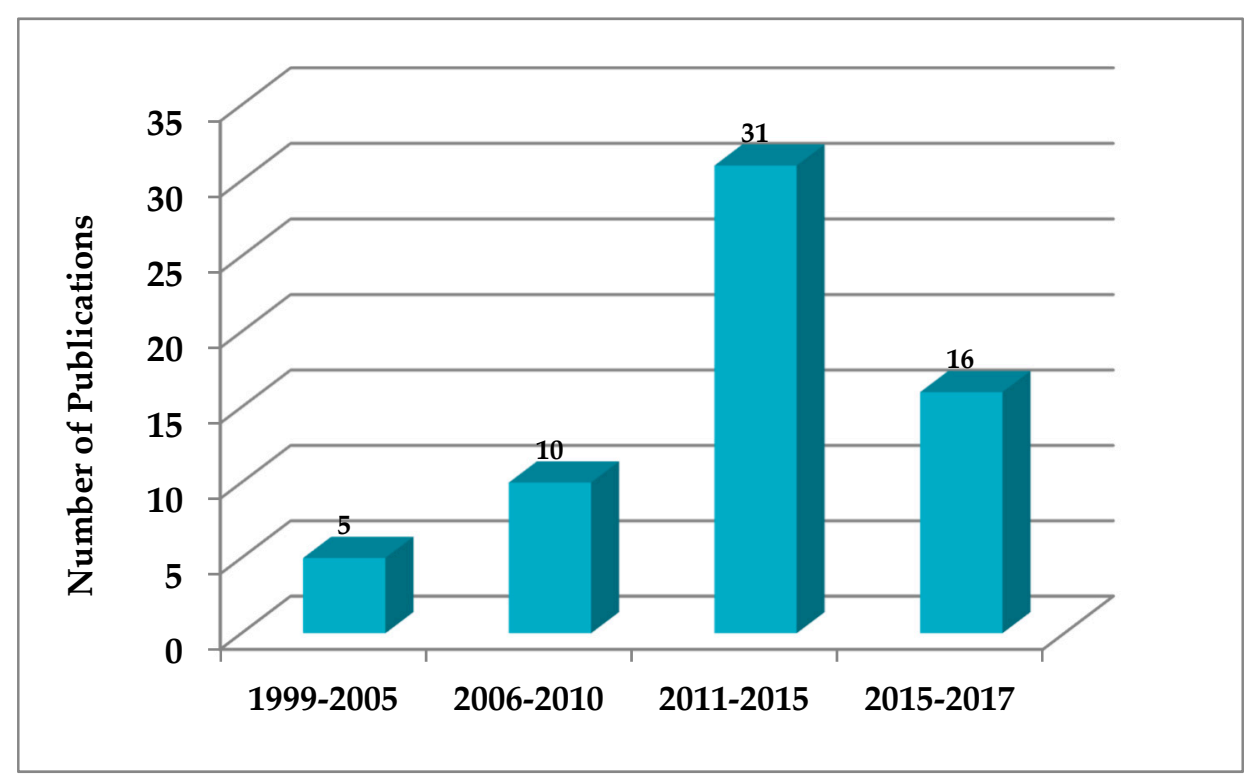

Figure 4. Number of Articles Selected from SCLRA and SLR according to Year.

Along with the passage of time in the construction industry, the certification level of green buildings is also increasing (Mutajwaa et al. 2016; Rashid et al. 2012; Li et al. 2017). The green building rating assessment tools provide the platform to the green building owner, developer and investor, etc. make their building certified as green (Krizmane et al. 2016). Additionally, green building assessment tools are not only easy to access but also save a lot of time in decision making at the earlier stages of building. The Green Building Rating Tool (GBRT) inspires developers and investors to bring their interest towards green buildings due to their strategic action plans (Nguyen and Altan 2011). However, various research mentioned that there is a lack of best green building rating assessment tools that are developed to integrate not only with the triple bottom line but also with some other essential tools that benefit all stakeholders (Doan et al. 2017). Table 2 shows an integrated matrix of selective critical literature review analysis from various research. This also examines their research approaches to various areas that contribute to green building, green building assessment tools and their associated tools. These terms have been identified as keywords used frequently within the selective critical literature review analysis. 
Table 2. Integrated Matrix Selective Critical Literature Review Analysis (SCLRA).

\begin{tabular}{|c|c|c|c|c|c|}
\hline Integrated Matrix of SCLRA & $\begin{array}{c}\text { Green } \\
\text { Buildings }\end{array}$ & $\begin{array}{l}\text { Green Building } \\
\text { Rating Tools }\end{array}$ & $\begin{array}{l}\text { Life Cycle } \\
\text { Costing }\end{array}$ & $\begin{array}{l}\text { Automation } \\
\text { in GBRT }\end{array}$ & $\begin{array}{c}\text { Sustainable } \\
\text { Development }\end{array}$ \\
\hline $\begin{array}{l}\text { Sustainable Development and Green Buildings } \\
\text { (Sinha et al. 2013) }\end{array}$ & $x$ & & & & $x$ \\
\hline $\begin{array}{l}\text { Developing a research framework for the green maintainability of buildings } \\
\text { (Chew et al. 2017) }\end{array}$ & $\times$ & & & & \\
\hline $\begin{array}{l}\text { Actors and barriers to the adoption of LCC and LCA techniques in the built environment } \\
\text { (D'Incognito et al. 2015) }\end{array}$ & & & $x$ & & \\
\hline $\begin{array}{l}\text { Evaluation of non-cost factors affecting the life cycle cost: an exploratory study } \\
\text { (Alqahtani and Whyte 2014) }\end{array}$ & & & $x$ & & \\
\hline $\begin{array}{l}\text { Comparative study of project management and critical success factors of greening new and existing } \\
\text { buildings in Singapore } \\
\text { (Sui Pheng et al. 2014) }\end{array}$ & $x$ & & & & \\
\hline $\begin{array}{l}\text { Towards a National Green Building Rating System for Malaysia } \\
\text { (Hamid et al. 2014) }\end{array}$ & & $x$ & & & \\
\hline $\begin{array}{l}\text { Automated Green Building Rating System for Building Designs } \\
\text { (Nguyen et al. 2012 ) }\end{array}$ & & $x$ & & $x$ & \\
\hline $\begin{array}{l}\text { Green Star Points Obtained by Australian Building Projects } \\
\text { (Xia et al. 2013) }\end{array}$ & & $x$ & & & \\
\hline $\begin{array}{l}\text { Green building research-current status and future agenda: A review } \\
\text { (Zuo and Zhao 2014) }\end{array}$ & $\times$ & & & & \\
\hline $\begin{array}{l}\text { Challenges in Delivering Green Building Projects: Unearthing the Transaction Costs (TCs) } \\
\text { (Qian et al. 2015) }\end{array}$ & $x$ & & $x$ & & \\
\hline $\begin{array}{l}\text { Sustainable energy performances of green buildings: A review of current theories, implementations } \\
\text { and challenges } \\
\text { (Ghaffarianhoseini et al. 2013) }\end{array}$ & $x$ & $x$ & & & \\
\hline $\begin{array}{l}\text { Green buildings, environmental awareness, and organizational image } \\
\text { (Rashid et al. 2012) }\end{array}$ & $\times$ & & & & \\
\hline $\begin{array}{l}\text { Developing a green building assessment tool for developing countries-Case of Jordan } \\
\text { (Ali and Nsairat 2009) }\end{array}$ & & $x$ & & & \\
\hline $\begin{array}{l}\text { Green Assessment Criteria for Public Hospital Building Development in Malaysia } \\
\text { (Sahamir and Zakaria 2014) }\end{array}$ & & $x$ & & & \\
\hline $\begin{array}{l}\text { Green Building Project Management: Obstacles and Solutions for Sustainable Development } \\
\text { (Hwang and Tan 2012) }\end{array}$ & $x$ & & & & $x$ \\
\hline
\end{tabular}


Table 2. Cont

\begin{tabular}{|c|c|c|c|c|c|}
\hline Integrated Matrix of SCLRA & $\begin{array}{c}\text { Green } \\
\text { Buildings }\end{array}$ & $\begin{array}{c}\text { Green Building } \\
\text { Rating Tools }\end{array}$ & $\begin{array}{l}\text { Life Cycle } \\
\text { Costing }\end{array}$ & $\begin{array}{c}\text { Automation } \\
\text { in GBRT }\end{array}$ & $\begin{array}{c}\text { Sustainable } \\
\text { Development }\end{array}$ \\
\hline $\begin{array}{l}\text { A comparative analysis of site planning and design among green building rating tools } \\
\text { (Huo et al. 2017) }\end{array}$ & & $\times$ & & & \\
\hline $\begin{array}{l}\text { Key criteria across existing sustainable building rating tools } \\
\text { (Krizmane et al. 2016) }\end{array}$ & & $x$ & & & \\
\hline \multicolumn{6}{|l|}{$\begin{array}{l}\text { Environmental, Economic, and Social Parameters in International Green Building Rating Tools } \\
\text { (Illankoon et al. 2016 ) }\end{array}$} \\
\hline $\begin{array}{l}\text { A Review on Green Building in Vietnam } \\
\text { (Nguyen and Gray 2016) }\end{array}$ & $x$ & $x$ & & & \\
\hline $\begin{array}{l}\text { Green building assessment tool (GBAT) for integrated BIM-based design decisions } \\
\text { (Ilhan and Yaman 2016 ) }\end{array}$ & & $x$ & & $\times$ & \\
\hline $\begin{array}{l}\text { Integrating life cycle assessment with green building and product rating systems: North American } \\
\text { perspective } \\
\text { (Collinge et al. 2015) }\end{array}$ & $\times$ & $x$ & & & \\
\hline $\begin{array}{l}\text { Sustainability and green building rating systems: LEED, BREEAM, GSAS and Estidama critical } \\
\text { analysis } \\
\text { (Awadh } 2017 \text { ) }\end{array}$ & & $x$ & & & \\
\hline $\begin{array}{l}\text { Research on the Construction of multidimensional CIS model in green building Based on } \\
\text { Experiment Simulation } \\
\text { (Li and Liu 2016) }\end{array}$ & $\times$ & & & & \\
\hline $\begin{array}{l}\text { Green building incentives: A review } \\
\text { (Olubunmi et al. 2016 ) }\end{array}$ & $x$ & $x$ & & & \\
\hline $\begin{array}{l}\text { Barriers to adoption of campus green building policies } \\
\text { (Hopkins 2016) }\end{array}$ & $x$ & & & & \\
\hline $\begin{array}{l}\text { A comparative review of environmental concern prioritization: LEED vs. other major certification } \\
\text { systems } \\
\text { (Suzer 2015) }\end{array}$ & & $x$ & & & \\
\hline $\begin{array}{l}\text { Key credit criteria among international green building rating tools } \\
\text { (Illankoon et al. 2017) }\end{array}$ & $\times$ & $x$ & & & \\
\hline $\begin{array}{l}\text { Ratio based indicators and continuous score functions for better assessment of building } \\
\text { sustainability } \\
\text { (Chandratilake and Dias 2015) }\end{array}$ & & $x$ & & & $\times$ \\
\hline
\end{tabular}


The above Table 2 integrated matrix also confers that there is a significant deficit of automation in green building assessment tools. However, life cycle costing issues are falling behind in integration within green building rating tools both locally and globally for better performance. This shows that there is need for additional facilitating tools integrating life cycle costing with GBI/Green RE/My CREST to assist investors perceptual experience and to lower perceptions of green building costs. The benefit of cost will evidently benefit the building projects in fetching more interest of investors, builders, developers, owners and occupants to the next level of quality in the built environment industry. This claim is further explored by Table 3, and the content of Table 3 has been selected from each paper's aim, objectives methodology and results in a thematic form after undergoing an intensive literature review regarding green building research. This will add in a better understanding of the literature available.

Table 3. Summarized Research Brief outline.

\begin{tabular}{ll}
\hline \multicolumn{1}{c}{ Researches } & \multicolumn{1}{c}{ Research Brief } \\
\hline & $\begin{array}{l}\text { This research provided an overview of how green building relates to sustainable } \\
\text { development practices. The research is carried on the simple theoretical framework } \\
\text { and the methodology used is table based analysis of literature review. The paper has } \\
\text { outlined the theoretical concept and analyzed the green building rating systems } \\
\text { overall but specifically critical evaluation (questionable rating) of LEED material \& } \\
\text { LEED performance of green building rating tool with evaluation of building } \\
\text { Green Buildings. } \\
\text { (Sinha et al. 2013) }\end{array}$ \\
& assessment as a potential green building rating system.
\end{tabular}

The research outlined a framework and development of new concept of green maintainability of buildings. This research was carried on conceptual knowledge building of green buildings after conducting thorough literature review. The research

Developing a research framework for the green maintainability of buildings. (Chew et al. 2017) found that limited literature is available on green maintainability as traditional maintainability is not cost effective with respect to facilities management. There is a potential to integrate Green Facilities Management along with green building tools for the maintainability of buildings as maintenance is one of the major costs in life cycle assessment and life cycle costs. However, Green Building Index and Green Building Tool along with Green Facilities Management can be developed to assess the green maintainability of green buildings.

This piece of research evaluated the slow adoption of life cycle costing and life cycle assessment with responsible factors. Theoretical concepts are used along with the literature review. Statistical tools, Delphi and Computer aided methods are used to validate and refine results. This research observed that the life cycle costing \& life cycle assessment has financial, technical and implementation barriers. Life cycle costing with green building tools can be assessed at various cultures/countries and observe on site application of these tools also barriers can be evaluated. The sample size of research can be widen to check the adoption of life cycle costing at different levels with other tools such as Project Management, Green Building Tool, etc.

adoption of LCC and LCA techniques in the built environment

(D’Incognito et al. 2015)

Evaluation of non-cost factors affecting the life cycle cost: an exploratory study

(Alqahtani and Whyte 2014)

This research has outlined the major factors of no costing impacting on life cycle costs. Theoretical approach of literature review interviews and a questionnaire survey from 138 completed building projects in UK were analyzed using a multiple regression method. Ten cost affecting factors have been found affecting accuracy of life cycle cost estimates. Project Management teams can use life cycle costs to find the best option available. Also this will enhance owner's satisfaction, cost drivers, and find control programs. Decision making system and green building tool can be incorporated to find the best life cycle costs. A web based automation of life cycle cost along with decision making system approach can be established to scrutinize the best option for project success.

Comparative study of project management and critical success factors of greening new and existing buildings in Singapore

(Sui Pheng et al. 2014)
This research examined the drivers, challenges and critical success factors involved in new and existing green building project in Singapore. Five major groups were formed from 28 selected factors from literature review. Then surveys and interviews were carried to validate CSFs identified factors. The research ranked the factors on the basis of comparison of new and existing buildings. Each category of identified factors have their own impacts in each criteria kept. These factors can be evaluated, Technology. analyzed and compared on green building tools to observe their viability in GB 
Table 3. Cont.

\begin{tabular}{|c|c|}
\hline Researches & Research Brief \\
\hline $\begin{array}{l}\text { Towards a National Green } \\
\text { Building Rating System for } \\
\text { Malaysia } \\
\text { (Hamid et al. 2014) }\end{array}$ & $\begin{array}{l}\text { This research presented the comparative review of four green building tools of } \\
\text { Malaysia GBI, PH-JKR, Green PASS, GreenRE. The in-depth interviews and } \\
\text { discussions were carried out. These rating tools were compared with various } \\
\text { sustainability issues. PH-JKR and Green PASS are merged to formulate National } \\
\text { Green Building Rating System which will facilitate all projects (government/private) } \\
\text { at the National level. This research helps in identifying the best tool to be used for } \\
\text { green building assessment. There is a potential to analyze global green building } \\
\text { rating tools and compare with Malaysian green building rating tools. Then, a new } \\
\text { green building rating tool can be formulated after examining shortfalls within } \\
\text { Malaysian green building rating tool for new and existing buildings. }\end{array}$ \\
\hline
\end{tabular}

This research has used the LEED green building rating system in BIM application to obtain an automated tool for better performance and rating. A BIM model and LEED criteria framework was developed and then both were combined in an automated

Automated Green Building Rating System for Building Designs

(Nguyen et al. 2012)

Green Star Points Obtained by Australian Building Projects (Xia et al. 2013)

Green building research-current status and future agenda: A review (Zuo and Zhao 2014)

Challenges in Delivering Green Building Projects: Unearthing the Transaction Costs (TCs) (Qian et al. 2015)

Sustainable energy performances of green buildings: A review of current theories, implementations and challenges

(Ghaffarianhoseini et al. 2013) computer BIM modeling to achieve a green building rating system through BIM. BIM \& LEED criteria and functions were combined in an automated way. Calculated LEED scores and rating level report was achieved. Some other green building rating systems can also be used in such type of automation. Potentially life cycle costing and life cycle assessment can also be added to get the best outcome and attract owners and project stakeholders through economic viability of automation and green building rating tool usages.

This research reviewed the usage of Green Star System in Australian building construction, and its challenges for achieving such certification by analyzing the Green Building Council Australia database. The theoretical approach with web based methodology was used to analyze the current certified buildings credits. The research showed that the 6 star green buildings mainly achieve management and innovation (energy) related credentials, while 4 star green building achieve more points in the material category. This study presents a useful referencing tool to understand rating systems. There is potential to evaluate the database of all certified buildings since the paper presented a thorough view and differences in the $6 \& 4$ star buildings. Secondly, it is possible to evaluate the Australian green building rating system and compare it with other countries to develop a better framework for industry.

The research depicted the picture of body of research and knowledge available in green buildings. Benefits of green buildings are compared to those for conventional buildings. This research performed theoretical research methodology by reviewing literature and green building rating system around the globe. Research showed that there is more focus on the environmental aspect of building in green building tools whereas social and economic aspects are comparatively lacking. Indeed many researchers have pointed out their importance. The life cycle assessment approach is extensively applied to environmental aspects, therefore there is a gap in terms of utilizing tools such as life cycle assessment and life cycle costing for evaluating social \& economic aspects in depth.

This piece of research identified the framework of activities associated with transaction costs in green building. In depth interviews were conducted from major developers in Hong Kong who had experience in green buildings. The study showed that the project planning stages are the major part in green buildings and real estate development as far as transaction costs are concerned. The results also identified "extra legal liability risk of the green building product" as the major concern for any green building developer in Hong Kong. It also showed that the transaction costs are the key factor in preventing green buildings from being constructed and these may vary from country to country. A new framework can be drawn to include green building rating systems to find out the impact of transaction costs on green buildings process and to suggest any automation tool that could attract industrial companies.

This research illustrated the sustainable energy performance of green buildings to contribute in sustainable development and $\mathrm{CO}_{2}$ emissions. The study carried a theoretical paradigm through a literature review. There is a great potential for solar panels on green buildings to reduce energy costs and $\mathrm{CO}_{2}$ emissions. It also concluded that it is hard to decide the energy solution for buildings especially in the case of green buildings, however these innovations can contribute to green building after lots of challenges and barriers in applicability. This kind of approach can be used for a case study to validate the implications of solar panels in green building systems in comparison to conventional buildings. 
Table 3. Cont.

\begin{tabular}{|c|c|}
\hline Researches & Research Brief \\
\hline $\begin{array}{l}\text { Green buildings, } \\
\text { environmental awareness, and } \\
\text { organizational image } \\
\text { (Rashid et al. 2012) }\end{array}$ & $\begin{array}{l}\text { This research study focused on the mechanism and impact of environmental design } \\
\text { of green buildings on occupant's environmental awareness \& organizational image. } \\
\text { The data was collected from } 175 \text { LEED certified green buildings using a } \\
\text { questionnaire. The approach of the study was to find direct and indirect effects of } \\
\text { environmental awareness and organizational image on occupants. It helps to identify } \\
\text { links between green buildings, environmental awareness \& organizational image. } \\
\text { The study found no evidence of direct effects of environmental design. The } \\
\text { individual workspace has some evidence of indirect effect of the satisfaction of } \\
\text { occupants. This study was conducted only on employees of the organization of } \\
\text { LEED certified building; hence there is a gap regarding research on a larger sample } \\
\text { with diverse occupants of LEED green buildings. }\end{array}$ \\
\hline
\end{tabular}

\section{Potential of LCC in Green Building and Green Building Rating Tools}

Life Cycle Costing (LCC) analysis is a method of determining the entire cost of a structure, product, or component over its expected useful life (D'Incognito et al. 2015). According to Okano (2001), life cycle costing analysis is an economic method that widely promoted in every building sector. It is a technique where all the owning and operating costs of the building is taken into consideration over whole life of the building or systems with a process in evaluating its performance. Life cycle costing estimates the total cost of the building from its initial construction through operation and maintenance of the building in order to explore the long term savings, identify the most cost-effectiveness system and determination of specific payback period. The essentiality of analysis is observed in every project since most of the industries are using it to control the initial and the future costs of a building. Mainly, it can be easily employed at any stage of design process with versatility to be used in new and existing building system evaluation. In addition, life cycle costing analysis can be taken into account to evaluate the project at various stages from whole site to a specific component of the building system (Zakaria et al. 2016).

Significantly, the study conducted earlier by Kats (2003) examined green buildings for 33 LEED projects financial and costs benefits in California, USA. The results outlined by investing just $2 \%$ extra in construction can lead to $20 \%$ savings from the long term perspective of costs. Cook et al. (2005) also identified 16 residential green building projects to examine and found that all of the projects have lower energy and water costs compared to conventional building except for one. Moreover, the study also mentioned that an average cost decrease of $34 \%$ in water, $35 \%$ in gas and $38 \%$ in electricity consumption have been identified for said projects.

Similarly, Kneifel (2010) conducted a study that examined the estimated life-cycle of energy saving, and reduction in carbon emission and their cost effectiveness in new commercial buildings by utilizing integrated design approach. This research also evaluated that by using available conventional energy efficient technologies, one can reduce the usage of energy by $20 \%$ to $30 \%$ on average, however, this can be increased to over $40 \%$ for some location, type and building. While two other researches' conducted by Langdon (2007) resulted that cost difference between LEED certified buildings and non LEED certified is not significant therefore easily one can achieve LEED certification status. Kats (2003) also performed research based on a web-based anonymous survey of 1200 LEED accredited professionals within Canada to assess the following areas: "practitioners' awareness, and confidence in research work assessing the cost premiums, long-term cost benefits, and health and productivity benefits of green buildings". This research also evaluated that green buildings have reduced usage of energy by an average of $33 \%$, that itself contributes to the cost saving over a 20 year of study period that is outbalanced by initial cost premium paid for such buildings. The study also estimated that savings will be achieved in years to come (20 years) in the forms of energy, water, productivity and health that will be approximately four to five times larger than the cost of the initial premium. The researchers Shah and Majumdar (2009) examined and found that in IIT Kanpur, India which is an institutional building, despite the $18 \%$ increase in investment for green building, the payback obtained occurs after only 4.8 years. That shows quite an attractive benefit and discussions with investors have proved that payback periods within 
10 years are readily accepted (Shah and Majumdar 2009). In addition, calculating the life cycle costs over 25 years for IIT buildings where the cost was initially higher turns out to be lower than those of the conventional building from the 5th year itself, indicating the savings.

Popescu et al. (2012) reviewed impact of energy efficiency measures on economic value of buildings and found two potential factors that can help to recoup investments; the first is energy savings potential and second is added value to the property. Vyas and Jha (2018) used probabilistic social cost-benefit analysis for green roofs and demonstrated that green roofs have better performance and are better short-term investments in terms of net returns. However, sustainable building has to be pivotal in their performances to keep them high and distinguished compared to conventional buildings as various studies have been assessed in Table 4, with fragmented topics, stages, parameters and approaches identified in the literature.

In life cycle costing analysis, the benefits of any system should be given critical importance and prior attention of decision makers (Snodgrass 2008). Benefits are difficult to justify accurately because they often tend to have intangible factors. Therefore, the variables of life cycle cost have to be accounted for seriously for an accurate analysis. This will bring about new trends and techniques for preserving natural resource and optimizing its efficiency. To act as an environmentally friendly industry, it needs to open its arms to new innovative technologies such as BIM, green IT, green technology, and integration of various tools (Deng and Wu 2014). However, there is still a need to develop a better, quick and time saving decision making tool. While green buildings have been available for many decades, there is now a vital way to improve them with scientific data and automated web-based systems (Pitt et al. 2009). This enhanced approach will increase investors' interest to invest in green buildings. Green building consultants, facilitators or green managers usually use manual methods to produce the rating index using the score and level of certification of green buildings, which increases the costs and decreases the interest of investors in green building development, especially in Malaysia. Therefore, automated tool of web-based system is needed to uplift investors' and developers interest towards green building development and it will also provide an easy, effective, efficient and quick assessment process of green building rating along with life cycle cost analysis. 
Table 4. Available Studies on the Costs Benefits of Sustainable Design.

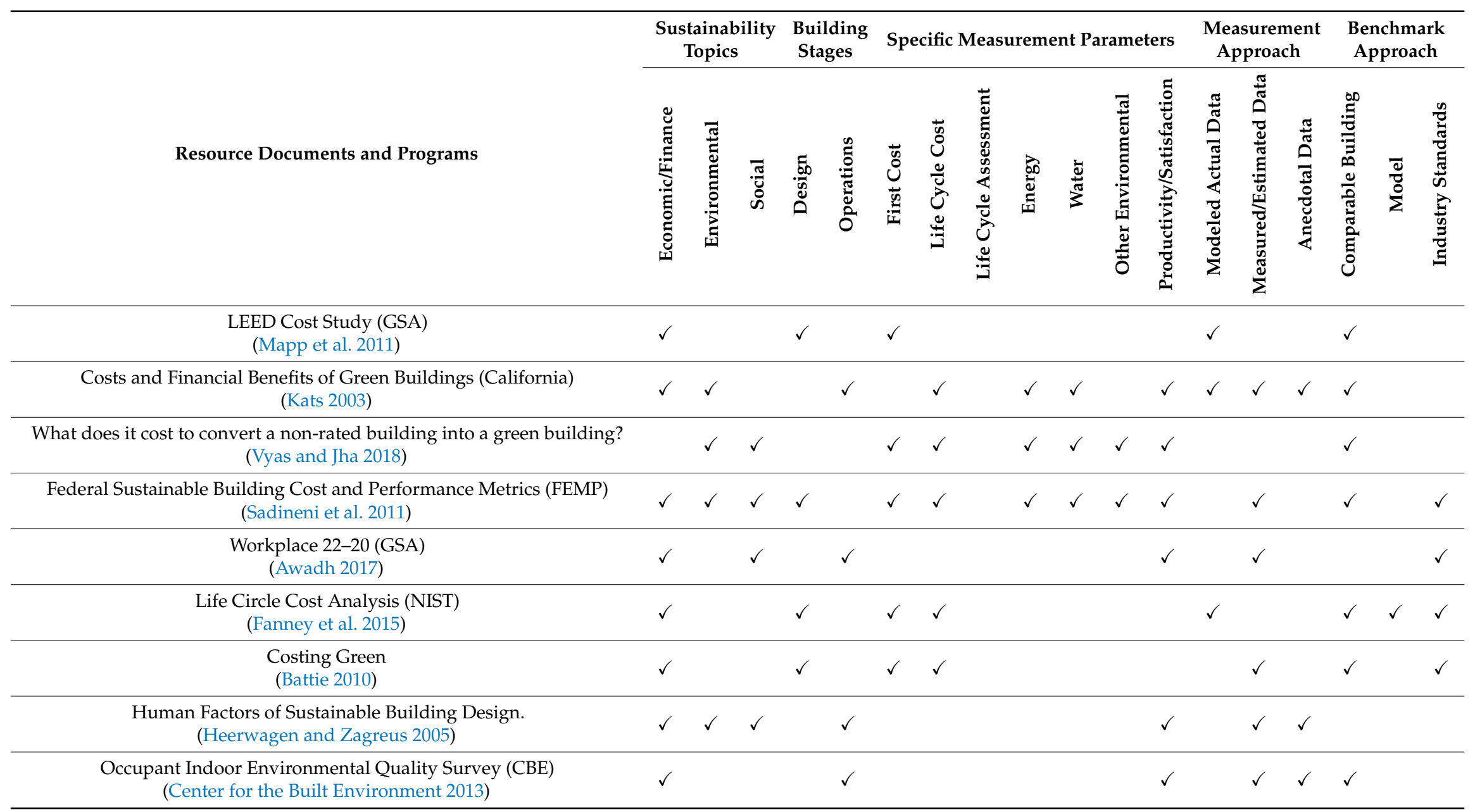




\section{Conclusions}

Evolution of green building from sustainable development has been a strenuous process for achieving sustainable development through its emergence in various areas. Green buildings play a vital role in the infrastructure development of countries and regions with a focus on the sustainable management of building from the design and construction to operation \& maintenance stages. The overall aim is to reduce resources degradation, impacts on climate and the emissions associated with buildings. To measure the performance of green buildings, various tools have been developed known as green building rating tools. These tools assess green buildings from cradle to grave. After assessment, buildings are certified as green buildings that show sustainable construction with a better quality of life.

Reviewing various literature that addresses the benefits of the green building demonstrates conclusively that green buildings provide with higher benefits than the conventional (non-green) buildings in all performance areas. Though, when the question arises of whether or not the cost premiums of green building are higher than conventional buildings, then most empirical studies reported in favor and very little evidence supported the theory that the green buildings costs are cheaper, varying from $-0.4 \%$ to $21 \%$ (Dwaikat and Ali 2016). Since green building requires various green technologies that are not used in conventional buildings, that can impact on cost escalation. Remarkably, the literature supported the theory that green buildings have evolved from sustainable development but there is still a lack of espousal in various countries, especially in developing countries.

However, many of the countries are also lacking in regard to green certified buildings and usage of green building rating tools that rigorously rate green buildings from design to demolition for certification. Various studies found a slow adoption of green buildings when there are no green building rating tools due to higher initial costs being associated with green buildings (Vyas and Jha 2018). However, there is potential to integrate green building rating tools with life cycle costing to identify various costs associated with green buildings such as energy efficient technology, sensor technology, and many other innovative green technologies. However, this gap needs to be filled to provide the construction industry with additional tools for next level of web-based automation and cost calculation. This will increase investor and developer interest with market appeal to the buyers in long term benefits. This can be seen as a call to perform more detailed research to assess published research in term of scientific cogency.

Author Contributions: J.S.K. and R.Z. edited, designed and developed original draft. N.I.A.A. and S.M.S. reviewed to enhance conceptualization. E.A., S.R.S. and D.N.A. designed methodology.

Funding: This research was funded by Ministry of Higher Education, Malaysia, Prototype Grant 4L685.

Acknowledgments: The authors would like to acknowledge the Ministry of Higher Education of Malaysia in sponsorship of fundamental grant and prototype grant of green building research. Highly gratitude's to authors/researcher from Universiti Teknologi Malaysia (UTM) for the financial support. Extended thanks to Universiti Teknologi MARA (UiTM) and co-authors and everyone who has been involved directly or indirectly for assisting and supporting this research.

Conflicts of Interest: The authors declare no conflict of interest.

\section{References}

Aktas, Bahacan, and Beliz Ozorhon. 2015. Green Building Certification Process of Existing Buildings in Developing Countries: Cases from Turkey. Journal of Management in Engineering 31: 05015002. [CrossRef]

Ali, Hikmat H., and Saba F. Al Nsairat. 2009. Developing a Green Building Assessment Tool for Developing Countries-Case of Jordan. Building and Environment 44: 1053-64. [CrossRef]

Alqahtani, Ayedh, and Andrew Whyte. 2014. Evaluation of Non-Cost Factors Affecting the Life Cycle Cost: An Exploratory Study. Journal of Engineering, Design and Technology 14: 818-34. [CrossRef]

Aras, G., and David Crowther. 2009. Making Sustainable Development Sustainable. Management Decision 47: 975-88. [CrossRef] 
Awadh, Omair. 2017. Sustainability and Green Building Rating Systems: LEED, BREEAM, GSAS and Estidama Critical Analysis. Journal of Building Engineering 11: 25-29. [CrossRef]

Battie, Mark. 2010. The Road to “Green Property.” Davis Landgon. vol. 7. Available online: http:/ /www.gbcsa.org. za/wp-content/uploads/2013/06/Davis-Langdon_Road-to-Green-Building-Handbook-2010.pdf (accessed on 26 March 2017).

Beatty, Balfour. 2011. Sustainability-A Collective Responsibility. Available online: http:/ /www.balfourbeatty. com/bby/media/publications/2009publ/vision_roadmap/vision_roadmap.pdf (accessed on 15 May 2017).

Bradley Guy, G., and Charles J. Kibert. 1998. Developing Indicators of Sustainability: US Experience. Building Research \& Information 26: 39-45. [CrossRef]

Center for the Built Environment. 2013. Center for the Built Environment: Occupant Indoor Environmental Quality (IEQ) Survey. Available online: https://www.cbe.berkeley.edu/research/survey.htm (accessed on 26 June 2018).

Chandratilake, S. R., and W. P. S. Dias. 2015. Ratio Based Indicators and Continuous Score Functions for Better Assessment of Building Sustainability. Energy 83: 137-43. [CrossRef]

Chew, M. Y. L., Sheila Conejos, and Ashan Senel Asmone. 2017. Developing a Research Framework for the Green Maintainability of Buildings. Facilities 35: 39-63. [CrossRef]

Collinge, W. O., C. L. Thiel, N. A. Campion, S. G. Al-Ghamdi, C. L. Woloschin, K. Soratana, A. E. Landis, and M. M. Bilec. 2015. Integrating Life Cycle Assessment with Green Building and Product Rating Systems: North American Perspective. Procedia Engineering 118: 662-69. [CrossRef]

Cook, D. J., N. L. Greengold, A. G. Ellrodt, and S. R. Weingarten. 1997. The Relation between Systematic Reviews and Practice Guidelines. Annals of Internal Medicine 127: 210-16. [CrossRef]

Cook, Madeline Fraser, William Bradshaw, Edward F. Connelly, Madeline Fraser Cook, and Lauren Baumann. 2005. The Costs \& Benefits of Affordable Housing. New Ecology. Available online: https:/ / www.newecology. org/wp-content/uploads / 2017/08/The-Costs-Benefits-of-Green-Affordable-Housing.pdf (accessed on 1 January 2018).

D'Incognito, Maria, Nicola Costantino, and Giovanni C. Migliaccio. 2015. Actors and Barriers to the Adoption of LCC and LCA Techniques in the Built Environment. Built Environment Project and Asset Management 5: 202-16. [CrossRef]

Deng, Yongheng, and Jing Wu. 2014. Economic Returns to Residential Green Building Investment: The Developers' Perspective. Regional Science and Urban Economics 47: 35-44. [CrossRef]

Doan, Dat Tien, Ali Ghaffarianhoseini, Nicola Naismith, Tongrui Zhang, Amirhosein Ghaffarianhoseini, and John Tookey. 2017. A Critical Comparison of Green Building Rating Systems. Building and Environment 123: 243-60. [CrossRef]

Dwaikat, Luay N., and Kherun N. Ali. 2018. The Economic Benefits of a Green Building-Evidence from Malaysia. Journal of Building Engineering 18: 448-53. [CrossRef]

Dwaikat, Luay N., and Kherun N. Ali. 2016. Green Buildings Cost Premium: A Review of Empirical Evidence. Energy and Buildings 110: 396-403. [CrossRef]

Economic Planning Unit Malaysia. 2016. Sustainable Development in Malaysia: '2030 AGENDA IN THE NATIONAL CONTEXT AND SDG ROADMAP'. Available online: http://onlineapps.epu.gov. $\mathrm{my} / \mathrm{sdg} /$ images/sdg_document_november/SDG_Malaysia_session_1_Datuk_Yoges.pdf (accessed on 19 September 2017).

Fanney, A. Hunter, Vance Payne, Tania Ullah, Lisa Ng, Matthew Boyd, Farhad Omar, Mark Davis, Harrison Skye, Brian Dougherty, Brian Polidoro, and et al. 2015. Net-Zero and beyond! Design and Performance of NIST's Net-Zero Energy Residential Test Facility. Energy and Buildings 101: 95-109. [CrossRef]

Ghaffarianhoseini, Amirhosein, Nur Dalilah Dahlan, Umberto Berardi, Ali Ghaffarianhoseini, Nastaran Makaremi, and Mahdiar Ghaffarianhoseini. 2013. Sustainable Energy Performances of Green Buildings: A Review of Current Theories, Implementations and Challenges. Renewable and Sustainable Energy Reviews. [CrossRef]

Grafakos, Stelios, Alberto Gianoli, and Alexandra Tsatsou. 2016. Towards the Development of an Integrated Sustainability and Resilience Benefits Assessment Framework of Urban Green Growth Interventions. Sustainability 8: 461. [CrossRef]

Greenbuildingindex Sdn Bhd. 2016. Green Building Index, Malaysia. Greenbuildingindex Sdn Bhd. Available online: http:/ / www.mgbc.org.my/ (accessed on 18 April 2018). 
Hamid, Zuhairi Abd, Maria Zura Mohd Zain, Foo Chee Hung, Mohd Syarizal Mohd Noor, Ahmad Farhan Roslan, Nurulhuda Mat Kilau, and Mukhtar Che Ali. 2014. Towards a National Green Building Rating System for Malaysia. Malaysian Construction Research Journal 14: 1-16.

Heerwagen, Judith, and Leah Zagreus. 2005. The Human Factors of Sustainable Building Design: Post Occupancy Evaluation of the Philip Merrill Environmental Center-Center for the Built Environment, Center for Environmental Design Research, UC Berkeley. Available online: https: / cloudfront.escholarship.org/dist/ prd/content/qt67j1418w/qt67j1418w.pdf?t=lptxbw (accessed on 2 August 2018).

Hopkins, Erin A. 2016. Barriers to Adoption of Campus Green Building Policies. Smart and Sustainable Built Environment 5: 340-51. [CrossRef]

Hu, Hong, Stan Geertman, and Pieter Hooimeijer. 2014. The Willingness to Pay for Green Apartments: The Case of Nanjing, China. Urban Studies 51: 3459-78. [CrossRef]

Huo, Xiaosen, Ann T. W. Yu, and Zezhou Wu. 2017. A Comparative Analysis of Site Planning and Design among Green Building Rating Tools. Journal of Cleaner Production 147: 352-59. [CrossRef]

Hwang, Bon Gang, and Jac See Tan. 2012. Green Building Project Management: Obstacles and Solutions for Sustainable Development. Sustainable Development 20: 335-49. [CrossRef]

Ilhan, Bahriye, and Hakan Yaman. 2016. Green Building Assessment Tool (GBAT) for Integrated BIM-Based Design Decisions. Automation in Construction 70: 26-37. [CrossRef]

Illankoon, I. M. Chethana S., Vivian W. Y. Tam, and Khoa N. Le. 2016. Environmental, Economic, and Social Parameters in International Green Building Rating Tools. Journal of Professional Issues in Engineering Education and Practice 143: 05016010-1. [CrossRef]

Illankoon, I. M. Chethana S., Vivian W. Y. Tam, Khoa N. Le, and Liyin Shen. 2017. Key Credit Criteria among International Green Building Rating Tools. Journal of Cleaner Production 164: 209-20. [CrossRef]

Kats, Gregory H. 2003. “Green Building Costs and Financial Benefits”. Available online: www.masstech.org (accessed on 27 September 2018).

Keyvanfar, Ali, Arezou Shafaghat, Muhd Zaimi Abd Majid, Hasanuddin Bin Lamit, Mohd Warid Hussin, Kherun Nita Binti Ali, and Alshahri Dhafer Saad. 2014. User Satisfaction Adaptive Behaviors for Assessing Energy Efficient Building Indoor Cooling and Lighting Environment. Renewable and Sustainable Energy Reviews 39: 277-95. [CrossRef]

Khan, Jam Shahzaib, Rozana Zakaria, Eeydzah Aminuddin, Nur Izieadiana Abidin, Shaza Rina Sahamir, Rosli Ahmad, and Darul Nafis Abas. 2018. Web-Based Automation of Green Building Rating Index and Life Cycle Cost Analysis. IOP Conference Series: Earth and Environmental Science 143: 1-13. [CrossRef]

Kibert, C. J. 2004. Green Buildings: An Overview of Progress. Journal of Land Use 19: 491-501. [CrossRef]

Kneifel, Joshua. 2010. Life-Cycle Carbon and Cost Analysis of Energy Efficiency Measures in New Commercial Buildings. Energy and Buildings 42: 333-40. [CrossRef]

Krizmane, Maija, Sandra Slihte, and Anatolijs Borodinecs. 2016. Key Criteria Across Existing Sustainable Building Rating Tools. Energy Procedia 96: 94-99. [CrossRef]

Langdon, D. 2007. Life Cycle Costing ( LCC ) as a Contribution to Sustainable Construction: A Common Methodology. Towards a Common European Methodology for Life Cycle Costing (LCC). Brussels: European Commission. (accessed on 19 August 2017).

Leiper, Q., N. Fagan, S. Engström, and G. Fenn. 2003. A Strategy for Sustainability. Proceedings of the ICE Engineering Sustainability 156: 59-66. [CrossRef]

Li, Jie, and Yan Liu. 2016. Research on the Construction of Multidimensional CIS Model in Green Building Based on Experiment Simulation. Paper presented at 2016 International Conference on Smart Grid and Electrical Automation (ICSGEA), Zhangjiajie, China, August 11-12; pp. 234-36. [CrossRef]

Li, Yuanyuan, Xiaochen Chen, Xiaoyu Wang, Youquan Xu, and Po Han Chen. 2017. A Review of Studies on Green Building Assessment Methods by Comparative Analysis. Energy and Buildings 146: 152-59. [CrossRef]

Mapp, Chad, Maryellen C. Nobe, and Brian Dunbar. 2011. The Cost of LEED-An Analysis of the Construction Costs of LEED and Non-LEED Banks. JORSE 3: 254-73.

McGraw Hill Construction. 2014. Canada Green Building Trends: Benefits Driving the New and Retrofit Market. Available online: https:/ / www.cagbc.org/cagbcdocs/resources/CaGBCMcGrawHillCdnMarketStudy.pdf (accessed on 14 September 2017).

MGBC. 2016. International Urban Sustainability \& Green Building Conference 2016. Available online: http:/ / www. mgbc.org.my/News/2016-05/Construction+_May_2016_Extract-1.pdf (accessed on 11 September 2017). 
MGBC. 2017. Malaysia Green Building Confederation (MGBC). Available online: http://www.mgbc.org.my/ (accessed on 9 July 2017).

Mutajwaa, Pantaleo, Daniel Rwelamila, and Neha Purushottam. 2016. Strategic Project Management as an Innovative Approach for Sustainable Green Campus Buildings in Africa: The Need for a Paradigm Shift. Smart and Sustainable Built Environment 5: 261-71. [CrossRef]

Nguyen, Binh K., and Hasim Altan. 2011. Comparative Review of Five Sustainable Rating Systems. Procedia Engineering 21: 376-86. [CrossRef]

Nguyen, Hong Trang, and Matthew Gray. 2016. A Review on Green Building in Vietnam. Procedia Engineering 142: 313-20. [CrossRef]

Nguyen, T. H., Sh H. Toroghi, and F. Jacobs. 2012. Automated Green Building Rating System for Building Designs. Journal of Architectural Engineering, 1-10. [CrossRef]

Okano, Kenji. 2001. Life Cycle Costing-An Approach to Life Cycle Cost Management: A Consideration from Historical Development. Asia Pacific Management Review 6: 317-41.

Olubunmi, Olanipekun Ayokunle, Paul Bo Xia, and Martin Skitmore. 2016. Green Building Incentives: A Review. Renewable and Sustainable Energy Reviews. [CrossRef]

Phillis, Yannis A., and Luc A. Andriantiatsaholiniaina. 2001. Sustainability: An Ill-de Ned Concept and Its Assessment Using Fuzzy Logic. Ecological Economics 37: 435-56. [CrossRef]

Pitt, Michael, Matthew Tucker, Mike Riley, and Jennifer Longden. 2009. Towards Sustainable Construction: Promotion and Best Practices. Construction Innovation: Information, Process, Management 9: 201-24. [CrossRef]

Plessis, Chrisna Du. 1999. Sustainable Development Demands Dialogue between Developed and Developing Worlds. Building Research E Information 27: 378-89. [CrossRef]

Popescu, Daniela, Sven Bienert, Christian Schützenhofer, and Rodica Boazu. 2012. Impact of Energy Efficiency Measures on the Economic Value of Buildings. Applied Energy 89: 454-63. [CrossRef]

Poveda, Cesar A., and Ryan Young. 2015. Potential Benefits of Developing and Implementing Environmental and Sustainability Rating Systems: Making the Case for the Need of Diversification. International Journal of Sustainable Built Environment 4: 1-11. [CrossRef]

Qian, Queena K., Edwin H. W. Chan, and Abd Ghani Khalid. 2015. Challenges in Delivering Green Building Projects: Unearthing the Transaction Costs (TCs). Sustainability 7: 3615-36. [CrossRef]

Rashid, Mahbub, Kent Spreckelmeyer, and Neal J. Angrisano. 2012. Green Buildings, Environmental Awareness, and Organizational Image. Journal of Corporate Real Estate 14: 21-49. [CrossRef]

Sadineni, Suresh B., Todd M. France, and Robert F. Boehm. 2011. Economic Feasibility of Energy Efficiency Measures in Residential Buildings. Renewable Energy 36: 2925-31. [CrossRef]

Sahamir, Shaza Rina, and Rozana Zakaria. 2014. Green Assessment Criteria for Public Hospital Building Development in Malaysia. Procedia Environmental Sciences 20: 106-15. [CrossRef]

Say, Candace. 2008. Sustainable Rating Systems around the World. Council on Tall Buildings and Urban Habitat Journal 2: 18-29.

Shafaghat, Arezou, Ali Keyvanfar, Muhd Zaimi Muhd, Hasanuddin Bin Lamit, Mohd Hamdan Ahmad, Mohamed Salim Ferwati, and Sib Krishna Ghoshal. 2016. Methods for Adaptive Behaviors Satisfaction Assessment with Energy Efficient Building Design. Renewable and Sustainable Energy Reviews. [CrossRef]

Shah, Sonam, and Mili (Guide) Majumdar. 2009. Study of Life Cycle Costing for Griha-Rated Green Buildings in India. Available online: http:/ / library.cept.ac.in/cgi-bin/koha/opac-detail.pl?biblionumber=32789\&query_ desc $=$ au\%3AShah\%2CSonamanditype\%3ATHEandavailable (accessed on 25 January 2018).

Shiel, Chris, Walter Leal Filho, Arminda do Paço, and Luciana Brandli. 2016. Evaluating the Engagement of Universities in Capacity Building for Sustainable Development in Local Communities. Evaluation and Program Planning 54: 123-34. [CrossRef] [PubMed]

Sinha, Arijit, Rakesh Gupta, and Andreja Kutnar. 2013. Sustainable Development and Green Buildings. Drona Industrija 64: 45-53. [CrossRef]

Snodgrass, Kathleen. 2008. Life-Cycle Cost Analysis for Buildings Is Easier than You Thought. United States Department of Agriculture. Available online: https://www.fs.fed.us/t-d/pubs/pdfpubs/pdf08732839/ pdf08732839dpi72.pdf (accessed on 25 July 2018).

Sui Pheng, Low, Gao Shang, and Tay Wen Lin. 2014. Comparative Study of Project Management and Critical Success Factors of Greening New and Existing Buildings in Singapore. Structural Survey 32: 413-33. [CrossRef] 
Suzer, Ozge. 2015. A Comparative Review of Environmental Concern Prioritization: LEED vs. Other Major Certification Systems. Journal of Environmental Management 154: 266-83. [CrossRef] [PubMed]

The World Bank. 2017. Population, Total. Available online: https://data.worldbank.org/indicator/SP.POP.TOTL? page $=2$ (accessed on 25 March 2018).

Towards Low-GHG and Resilient Buildings. 2016. Global Alliance for Buildings and Construction. Available online: https:/ / wedocs.unep.org/rest/bitstreams/45611/retrieve (accessed on 23 June 2018).

UK-Green Building Council. 2014. Key Statistics: International | UK Green Building Council. Available online: http:/ / www.ukgbc.org/resources/additional/key-statistics-international (accessed on 11 January 2018).

UNEP. 2012. United Nations Environment Programme 2012 Annual Report. Available online: http://staging. unep.org/gc/gc27/docs/UNEP_Annual_Report_2012.pdf (accessed on 17 September 2017).

United Nations Publcation. 2007. Indicators of Sustainable Development: Guidelines and Methodologies. New York: United Nations. (accessed on 25 May 2018).

USGBC-LEED+ND. 2014. Getting to Know LEED: Neighborhood Development I U.S. Green Building Council. Available online: https:/ / www.usgbc.org/articles / getting-know-leed-neighborhood-development (accessed on 21 May 2017).

USGBC. 2017. USGBC Statistics I U.S. Green Building Council. Available online: https://www.usgbc.org/ articles/usgbc-statistics (accessed on 2 October 2018).

Vyas, G. S., and K. N. Jha. 2018. What Does It Cost to Convert a Non-Rated Building into a Green Building? Sustainable Cities and Society 36: 107-15. [CrossRef]

WCED. 1987. Report of the World Commission on Environment and Development: Our Common Future (The Brundtland Report). vol. 4. Available online: http://mom.gov.af/Content/files/Bruntland_Report.pdf (accessed on 13 September 2017).

WGBC. 2016. WORLD GREEN BUILDING COUNCIL Annual Report 2015/2016. Available online: http: / / www. worldgbc.org/sites/default/ files/P578WGBCAnnualReport_LR4.pdf (accessed on 11 November 2017).

WGBC. 2017. Rating Tools I World Green Building Council. Available online: http://www.worldgbc.org/ratingtools (accessed on 23 April 2017).

WGBT. 2016. World Green Building Trends 2016. Available online: http://www.czgbc.org/Download/ WorldGreenBuildingTrends2016SmartMarketReportFINAL.pdf (accessed on 1 August 2017).

World Green Building Council. 2017. Green Building \& the Sustainable Development Goals I World Green Building Council. Available online: http:/ / www.worldgbc.org/green-building-sustainable-developmentgoals (accessed on 3 June 2017).

Xia, Bo, Jian Zuo, Martin Skitmore, Stephen Pullen, and Qing Chen. 2013. Green Star Points Obtained by Australian Building Projects. Journal of Architectural Engineering 19: 302-8. [CrossRef]

Zakaria, Rozana, Yakubu Aminu Dodo, Rosli Ahmad, Nur Izieadiana, and Binti Abidin. 2016. Proposed Market Survey Framework for Build Green in Malaysia. Journal of Applied Sciences E Environmental Sustainability 2: 115-25.

Zhou, Yang. 2014. Comparison of Chinese Green Building Standard with Western Green Building Standards. KTH Engineering and Management. Available online: http:/ / www.diva-portal.org/smash/get/diva2:735240/ FULLTEXT01.pdf (accessed on 29 May 2017).

Zuo, Jian, and Zhen Yu Zhao. 2014. Green Building Research-Current Status and Future Agenda: A Review. Renewable and Sustainable Energy Reviews. [CrossRef]

(C) 2019 by the authors. Licensee MDPI, Basel, Switzerland. This article is an open access article distributed under the terms and conditions of the Creative Commons Attribution (CC BY) license (http://creativecommons.org/licenses/by/4.0/). 